\title{
VIOLÊNCIA DA MÍDIA, \\ TECNORRACIONALISMO E CIDADANIA
}

\author{
MEDIA VIOLENCE, \\ TECHNO RATIONALISM AND CITIZENSHIP
}

\section{MAGNO MEDEIROS}

Doutor pela Universidade de São Paulo (USP), Magno Medeiros é professor do Programa dePós-Graduação em Comunicação da Faculdade de Comunicação e Biblioteconomia da Universidade Federal de Goiás (UFG), onde também atua como Diretor da Faculdade

\section{RESUMO}

O texto discute a relação entre mídia e cultura da violência, abordando as possíveis formas de impacto junto à sociedade. A violência na/da mídia deve ser pensada, sobretudo, a partir da atual cultura midiática e do atual ambiente tecnorracionalista. Entendendo-se por tecnorracionalismo todo um conjunto complexo e articulado de valores, símbolos, ideologias e conceitos cultivados, cultuados e irradiados pelos meios de comunicação contemporâneos. Trata-se, pois, do aparato socioestrutural que promove a dissolução gradual e persistente das potencialidades do sujeito comum. Nessa teia ou rede de valores, constrói-se a cultura da violência. Vivemos, hoje, uma cultura que naturaliza a violência. $O$ artigo aborda, assim, questões como a espetacularização do real, a banalização da violência, a repetição e a saturação do sentido.

Palavras-chave: Comunicação; mídia; violência; cidadania.

\section{ABSTRACT}

This text discusses the relation between media and cultural violence, broaching the possible ways of its impact on society. The media violence or the violence at the media must be thought, especially from the nowadays media culture and the techno rationalism sphere. Techno rationalism is a well founded and a complex whole of values, symbols, ideologies and well developed, worshiped and irradiated concepts through the contemporaneous media. This is about a socio structural apparatus that causes the gradually and continuous dissolution of the common individual potentialities. It is built a violence culture on the network values. We live, today, a culture that natura-lizes violence. So, this study leads with subjects such as the reality performance, violence vulgarization and the repetition and the saturation of the sense.

Keywords: Communication; media; violence; citizenship. 


\section{Apresentação}

Se a mídia é, atualmente, um fenômeno onipresente no imaginário social, não o seria tanto se não cultivasse a violência como um dos principais ingredientes de sedução e atração. Como se nota, os tradicionais campeões de audiência são justamente os filmes, seriados, novelas e telejornais repletos de explosões, tiros, agressões físicas e verbais, perseguições policiais, enfim, muito sangue, velocidade e ação. O presente artigo tem por objetivo analisar a violência midiática em seu contexto tecnocrático, abordando como e por que imagens de violência são exploradas e hipervalorizadas, realimentando o imaginário sombrio dos receptores - seus medos, suas perplexidades e mistérios, seus desejos, suas angústias e sua insegurança. $\mathrm{E}$, com isso, garantindo mais alguns pontos de audiência: meta suprema dos mass media.

\section{Mídia e violência: conceitos}

A origem etimológica da palavra "violência" remonta ao termo latino violentia (força, caráter bravio ou violento) e ao verbo $v i$ olare (transgredir, profanar, tratar com violência). O núcleo de significação "vis" denota força, vigor, potência, violência, emprego de força física, mas também quantidade, abundância, essência de alguma coisa. Em suma: força em ação (MICHAUD, 1989, p. 22).

Michaud aponta duas orientações principais para o termo violência:
1) de um lado, designa ações e fatos (neste caso, a violência se opõe à paz e à ordem);

2) de outro lado, diz respeito a uma maneira de ser da força, do sentimento ou de um elemento natural - paixão, natureza (neste caso, a violência é uma força brutal que desrespeita as regras e passa da medida). (MICHAUD, 1989, p. 7)

Em termos mais simples, podemos classificá-la em:

1) Atos de violência: Neste caso, a violência está presente em atos concretos de agressão, destruição e transgreção das regras e da ordem vigente. São atos factuais, visíveis, materiais, brutais, e que podem sofrer as penalidades na esfera do direito, principalmente na do direito criminal. Este tipo de ato ou conduta é também denominada de "violência vermelha". (MORAIS, 1981)

2) Estados de violência: Neste caso, a violência está oculta em estados sutis de uso da força. Já não se trata mais de atitudes brutais, mas de uma situação ou circunstância social que oprime, reprime, violenta, gradualmente, às vezes até de forma quase imperceptível. Estamos, pois, diante de uma "violência branca" (MORAIS, 1981), que se faz presente nas instituições, nos serviços (ou desserviços) do Estado, nos sistemas tecnoburocráticos, nos mecanismos ideológicos de controle social.

Como se observa, de um lado temos uma categoria de violência que se manifesta em "atos" (brutais); e de outro lado, uma violência que se oculta em "estados" (sutis). A dificuldade de se definir 
precisamente o termo violência deriva do fato de que - num sentido mais amplo - a violência pode existir em todos os lugares onde houver transgressão, seja ela brutal ou sutil.

Desta perspectiva, afirma Michaud (1989, p. 08), "podem haver quase tantas formas de violência quantas forem as espécies de normas." Exatamente por isso Michaud adverte que não há um saber universal sobre a violência e que as definições objetivas, ainda que bastante úteis, não estão isentas de pressupostos diversos e não conseguem apreender o conjunto dos fenômenos sociais. Ainda segundo o autor, uma definição plausível do termo violência deve dar conta de uma série de fatores importantes.

São eles:

1) A violência pode ser produto de múltiplos atores, às vezes até máquinas administrativas (sistemas tecnoburocráticos, máquinas judiciárias, regimes totalitários);

2) A diversidade de instrumentos usados para se praticar a violência (as próprias mãos, uma arma de fogo, um ordem de bombardeio etc.);

3) A duração da violência ("timing ").Podeela seraplicada em uma única vez (maciça) ou gradualmente (distribuida), eventualmente até de forma imperceptivel. Por exemplo, pode-se matar, deixar morrer de fome ou abandonar a população a míseras condições de sobrevivência (subnutrição).

4) Os diferentes tipos de danos: fisicos, psíquicos, morais, aos seus bens, aos próximos ou aos seus laços culturais. (MICHAUD, 1989, p.11)
Desta forma, Michaud assim formula um abrangente conceito de violência, que possui a vantagem de abarcar tantos os "atos" quanto os "estados" violentos:

Há violência quando, numa situação de interação, um ou vários atores agem de maneira direta ou indireta, maciça ou esparsa, causando danos a uma ou várias pessoas em graus variáveis, seja em sua integridade fisica, seja em sua integridade moral, em suas posses, ou em suas participações simbólicas e culturais. (MICHAUD, 1989, p.10-11)

Os mass media supervalorizam matérias sobre crimes, estimulam o apetite criminoso, sancionam o mórbido e distorcem valores ético-morais. Neste sentido, há uma grande e negativa difusão de "informações criminógenas", ou seja, informações sobre fatos antisociais e violentos, que possam vir a influenciar ou incitar o receptor ao crime. Segundo os criminólogos, o perigo é que certas "informações criminógenas" possam induzir ao "fator criminógeno". De acordo com Michaud (1989), a violência na mídia é, acima de tudo, um produto espetacular. Neste sentido, há duas questões fundamentais a se levar em consideração:

1) A violência na TV é mediada pela imagem, como tudo o que passa pelo ecrã luminoso. Neste sentido, as imagens passam pelas distorções próprias da linguagem televisiva, que vão desde o enfoque dado à matéria até o formato editorial que ela assumirá enquanto imagem. Com efeito, uma vez mediada pelas imagens 
televisivas, a realidade será em grande parte ilusória. "É aqui que ocorrem todas as possibilidades de desinformação: desinformação por retenção de informação, por manipulação desinformação, por excesso de informação também. (MICHAUD, 1989, p.50)

2) A violência na TV é tratada de forma irreal e banalizada. As imagens apresentadas são espetaculares, brilhantes "como papel celofane". Ou seja: as imagens de violência perdem o seu dramadenúncia, o seu poder de indignação. Enfim, são mostradas como normais e menos terríveis.

As imagens da violência apresentam desta uma versão edulcorada: violência em papel brilhante, violência com celofane. Se é verdade que a experiência contemporânea da violência passa em grande parte pelas imagens, tal experiência só pode ser suavizada e banalizada. É nesse sentido que as imagens da violência são perigosas. (MICHAUD, 1989, p.51)

\section{Mídia e violência tecnorracionalista}

Não pretendemos abordar especificamente a violência na mídia, mas, sobretudo, a violência da mídia, caracterizada, atualmente, pela cultura tecnocrática. Mas o que é violência tecnorracionalista? É aquela que emana e se constrói a partir das estruturas sociais dominantes. Resultante do racionalismo e burocratização ocidentais, ela é implícita, dissimulada e subjacente. Às vezes, é subliminar, constituindo-se às sombras da mensagem manifesta. Faz-se mais pelo que deixa de apresentar, pelo que esconde e oculta nas entrelinhas de determinadas mensagens.

Assim, há violência tecnorracionalista quando todo um aparato socioestrutural promove uma dissolução gradual e persistente das potencialidades do sujeito comum. Trata-se de uma violência invisível (ou quase), na medida em que ela se manifesta não no conteúdo aparente dos objetos, fatos, fenômenos e imagens, mas no modo como relaciona o sujeito ao mundo instituído.

A violência racionalista está presente em gêneros diversos e pode também ser analisada na esfera dos discursos ideológicos. Assim, cenas de violência implícita podem ser detectadas, por exemplo, em imagens de preconceito racial, social, religioso, político ou cultural, atentando-se, neste caso, contra os direitos humanos e contra os espaços de cidadania.

Na sociedade contemporânea, quase não há mais uma manipulação política direta, frontal e repressora, posto que os poderes instituídos da violência totalitária são cada vez mais sutis e "sedutores". Também não há mais uma alienação politicamente globalizante, pois os sujeitos agem e reagem de forma ativa (mas também passiva), selecionando os produtos de consumo cultural e material.

O projeto de modernização da sociedade ocidental previa a racionalização de todos os segmentos sociais. Porém, com o advento das culturas pós-modernas ${ }^{1}$ surgiu uma hiper-racionalização social, cuja marca fundamental passou a ser burocracia ou tecnoburocracia. Segundo Maffesoli (1981), as
10 termo "pós-modernidade" já havia sido proposto nos anos 1950 e 1960, mas o seu conceito só foi consolidado a partir da segunda metade dos anos 1970, principalmente com a publicação de La condition postmoderne (1979), de Jean-François Lyotard. 
formas de opressão e de controle tecnoburocrático constituem a chamada violência totalitária. Esta modalidade de violência é exercida através dos poderes instituídos, dos Estados, dos serviços burocráticos, da morosidade dos serviços públicos, do desrespeito institucional às próprias leis instituídas.

Sonegar informações, falsificar dados de interesse público, omitir pontos negativos acerca de uma dada administração, tudo isso pode ser considerado como violência institucional. Indignação e frustração. Estas são as sensações predominantes de quem se vê "violentado" pela morosidade, burocracia e ineficácia dos serviços públicos prestados no Brasil.

O descaso dos governos para com os serviços públicos é tratado, hoje, com tanta indignação como a burocracia no atendimento ou falta de atendimento à comunidade. Este tipo de violência é relatado pela sociedade como contundente agressão à cidadania, sem cuja condição não é possível respeitar os direitos sociais e individuais inerentes a todos os seres humanos. "Para mim, burocracia é um tipo de violência", esta frase é freqüentemente ouvida pela população brasileira, indignada com a morosidade, a desinformação e os entraves dos serviços públicos.

Segundo Arendt, a burocracia - criação-mor do tecnorracionalismo - tornou-se, principalmente a partir dos anos 1970, a mais nova forma de controle social, um controle "astuto" onde predomina um domínio "anônimo":

Hoje devemos acrescentar a mais nova e talvez a mais for- midável forma desse domínio: a burocracia ou o domínio de um intrincado sistema de órgãos no qual homem algum pode ser tido como responsável, e que poderia ser chamado com muita propriedade o domínio de Ninguém. (ARENDT, 1985, p. 20-21)

Referindo-se às tentativas do cidadão comum de identificar e de responsabilizar alguém pelas opressões cotidianas das quais é vítima, Arendt (1985) entende que os serviços burocráticos são absolutamente tirânicos, na medida em que consegue mascarar uma violência exercida de forma sutil. Acuado, sem ter a quem recorrer, o cidadão comum é incitado à rebeldia e à violência.

Usando a terminologia de Maffesoli (1981), a tendência desse cidadão oprimido é, portanto, responder a essa violência totalitária (tecnoburocracia) através de atos de violência banal (pichações, por exemplo) ou, o que seria pior, através de violência anômica (homicídios, por exemplo).

A meta da violência totalitária é o controle racionalizado e centralizado da vida social, por meio das instituições e órgãos policiais, fiscais, judiciários, militares. A conseqüência será a domesticação das paixões, da agressividade, dos desejos, em prol do trabalho, ou melhor, da manutenção da cadeia tecnoprodutiva.

Assim, as instituições, isto é, os poderes instituídos (Estado, partidos, organizações criminosas) esforçam-se sempre para manter o monopólio da violência. E isto, segundo Maffesoli (1981, p. 16), tem ocorrido com força nos dois últimos séculos: "Tudo foi arran- 
jado para que as zonas obscuras do social desaparecessem em benefício de uma asséptica normalidade. Delimita-se o desvio, a disfunção para melhor tratá-los". E prossegue o autor: "É necessário e suficiente que a anomia que foi marginalizada sirva de justificativa a toda uma categoria de especialistas (...) que constituirão o que se convencionou chamar de tecnoestrutura contemporânea." (idem, p. 16)

E os meios de comunicação de massa são co-participantes nesse processo de violência totalitária, na medida em que passou a ser o principal foco de irradiação do ethos tecnorracionalista. Então, podemos dizer que a violência tecnorracionalista permeia, de forma invisível, as imagens da televisão.

\section{A violência da TV: espetacularização e volaticidade}

Há violência implícita também quando a TV, por meio de seus programas, omite fatos jornalísticos relevantes ou veicula acusações falsas ou sem provas contra determinadas pessoas, instituições, entidades ou empresas sem lhes dar nenhum direito de resposta. $\mathrm{O}$ recurso do corte e da edição, próprios da produção televisiva, tem facilitado o cerceamento de vozes contraditórias e divergentes.

Muitas vezes, a TV tem impossibilitado o raciocínio e a argumentação, indispensáveis à educação da cidadania; outras vezes tem contribuído para criar um clima de medo e insegurança entre a população. Neste sentido, os mass media operam, sobretudo, fluxos informativos desmaterializados e desumanizados.
O receptor, assim, não obstante a sua relativa atividade, é importante para a estrutura tecnorracionalista muito mais por se constituir um número a mais nos índices de audiência do que por seu olhar, impregnado de desejos e medos. É neste sentido também que podemos falar de uma certa "desmaterialização" do ser humano.

Assim, é a violência tecnorracionalista: quase tudo se encontra burocratizado, até as formas de liberação/extravasão de energias afetivo-sentimentais e agressivas. Para a tecnoestrutura só importa o fluxo informacional; os sentimentos pessoais são sistematicamente ignorados pelo hiper-racionalismo contemporâneo.

Os jovens, particularmente, são oprimidos em seus fluxos sentimentais, em detrimento dos fluxos eletrônicos. Por isso, costuma-se dizer que somos a sociedade da informação e não da comunicação, entendida esta num sentido mais amplo de relações humanas múltiplas, interrelações pessoais, trocas simbólicas. Mas, conforme afirma Maffesoli (1981), essas repressões/ opressões, racionalistas ou hiper-racionalistas (violência totalitária), desencadeadas no plano do social, são violadas no plano da socialidade, ${ }^{2}$ seja através de resistências populares diversas (violência banal), seja através de agressões diretas, ilegais e criminosas (violência anômica). A violência na $T V$, apesar de garantir a audiência e conseguir prender $\mathrm{o}$ telespectador, de uma forma geral não consegue despertar a ação o sujeito-consumidor; não consegue mobilizar a sua indignação; nem é capaz de despertar a sua imaginação mais criativa e simbólica.
2 Socialidade é o modo através do qual os indivíduos vivem/vivenciam o "estar-junto", condição peculiar à "solidariedade orgânica" e não a uma "solidariedade mecânica". 
3 "Zapeador" e uma forma aportuguesada usada para se referir à pessoa que se utiliza do recurso do zapping (inglês), isto é, que usa o controle remoto para mudar os canais ou acionar certos comandos de um aparelho eletrônico (TV, por exemplo).
A insistência do telespectador delineia um tipo de olhar obsessivo, que "degusta" todo tipo de imagem, mesmo não se sentindo seduzido por elas. É o telespectador do tipo: "Vi, não gostei, continuo vendo". Com efeito, os milhões de telespectadores se armam do controle remoto para oscilar de um canal a outro. É o telespectador contemporâneo, pós-moderno: um "zapeador" 3

Assim, prossegue o "zapeador" em sua ambígua audiência televisiva. Ele vai assistindo a um desconexo programa de televisão, construído por meio da passagem rápida e obsedante pelos vários canais. Trechos de "spots" publicitários, de programas de auditório, novelas, futebol, seriados, telejornais, filmes, mesclam- se através de uma colagem proporcionada pelo controle remoto. Elabora-se, assim, uma grande (indigesta?) salada de imagens.

Como se vê, não há um interesse específico por este ou por aquele programa de televisão, já que eles se equivalem uns aos outros. Há como que um nivelamento por baixo: de um modo geral, a qualidade televisiva parece ser tão insatisfatória que os receptores não conseguem fixar-se em nenhum deles. Por isso, acabam transformando-se em "zapeadores", nova tendência da pós-modernidade.

Essa cultura da velocidade, da volaticidade, da dispersão, da superficialidade, do excesso, marca, portanto, não só uma nova era, como também uma nova forma de "agressão": a invisível violência tecnorracionalista.

Esse contexto tecnorracionalista resulta em uma tosca realidade: a banalização da violência.
Fruto da superexposição de imagens violentas pelos media, o sujeito vai, gradualmente, perdendo a sensibilidade social ou, no mínimo, o sentimento de estranheza, diante de tais imagens.

Assim, a violência está ganhando cada vez mais ares de normalidade e naturalidade, além de estar alcançando uma crescente aceitabilidade social. Sua inevitabilidade tem gerado atitudes do tipo: "deixa rolar"; "não tem jeito mesmo". Esse comodismo reflete a saturação não só de sensibilidade social (solidariedade humana) como também o esgotamento de ações políticas e judiciárias.

No contexto dessa cultura da violência em que vivemos hoje, os criminosos perderam quase completamente a sua consciência de culpa. Segundo Freire Costa (1986), eles não se julgam mais fora da lei ou da moral, pois agem de acordo com o que eles próprios estipulam ser o preceito correto e o incorreto.

Neste sentido, criou-se e se mantém um tipo de cultura em que o outro não representa mais o próximo, idéia que remete ao ser humano. O outro - aquele com quem você pode cruzar involuntariamente pelos espaços da metrópole - é simplesmente o outro: um corpo isento de proximidade, de familiaridade, de comunidade, de humanidade.

Este é exatamente o sentido da violência tecnorracionalista: 0 ser humano deixa de existir enquanto uma figura de trocas afetivas para se transformar numa figura anônima, desumanizada, desinvestida de "reconhecimento" social e de "identidade" pessoal. Repita-se: numa cultura tecnorra- 
cionalista, como a atual, impera o código da banalização. Significa, portanto, que persiste uma cultura que desvaloriza o sentimento, a sensibilidade e a solidariedade. Com tal derrocada do sujeitopróximo, com tal transformação do indivíduo-parceiro em apenas um número, um corpo errante no meio de milhões de outros corpos, a conseqüência prática e absurda da cultura tecnorracionalista será a destruição do outro e de si mesmo. Pois o outro, principalmente se pertencer aos setores marginalizados e excluídos da sociedade, será meramente outrem, não será considerado gente.

A imoralidade da cultura da violência, segundo Freire Costa (1986), consiste justamente na disseminação de sistemas morais particularizados e irredutíveis a ideais comuns, condição prévia para que qualquer atitude criminosa possa ser justificada e legitimada por eles. No Brasil, supõe-se que isso tenha se agravado nos últimos anos em decorrência da impunidade aos crimes, principalmente os de maior repercussão (escândalos políticos, corrupção, "crime do colarinho branco" são apenas alguns exemplos).

Primeiramente, é preciso considerar que a violência, enquanto produto simbólico, mobiliza toda uma coletividade, especialmente quando o meio de comunicação de massa (a televisão) atinge milhões de espectadores no Brasil. E a indignação decorrente, da mesma forma, permeia toda a sociedade. Daí se falar em indignação coletiva, e não simplesmente pessoal. (TILLY, 1978)

$\mathrm{O}$ indivíduo, de maneira geral, se insurge contra atos e fatos violentos, principalmente quando se estabelece a impressão (verdadeira ou falsa) de que a violência possa estar próxima de si ou de seus pares; quando ela é uma ameaça iminente, possível e até mesmo provável. Então, a indignação transcende o âmbito pessoal para atingir todo um grupo ou classe social.

O problema de muitos jovens refere-se, geralmente, à insatisfação generalizada pela programação televisiva, perceptível na maioria dos telespectadores brasileiros. Normalmente, os jovens reclamam da falta de opções de programas na TV que pudessem se voltar às especificidades de sua idade: seus interesses, seus desejos, suas expectativas, seus sonhos.

Esse tipo de nivelamento da programação, calcada em estereótipos e "fórmulas de audiência", constitui em mais um tipo de violência invisível: tecnorracionalista. Um tipo de violência que despreza a inteligência do receptor e, principalmente, congela, dilui ou volatiliza o seu poder de imaginação criativa. Assim, ver TV é um ato, geralmente, desprovido de imagens instauradoras da criatividade imaginante. Diante da TV, dificilmente se consegue imaginar de forma criativa (simbólica, mítica, cósmica, fantástica e oniricamente). Assim, televisão acaba sendo refratária ao pensamento, quanto mais à imaginação.

Com efeito, o que se passa na cabeça do receptor? Em seu imaginário, dificilmente passarão imagens irruptoras.

\section{Banalização, repetição e saturação do sentido}


Outra questão importante na temática da violência na televisão é a forma repetitiva com que essas imagens chegam aos lares dos receptores. Trata-se de violência obsessiva, marca fundamental da violência tecnorracionalista. Há na televisão um excesso de cenas fortes, imagens de violência. É possível ver imagens violentas em todos os horários e em quase todos os programas, o que só reforça a constatação de que violência é realmente "prato cheio" para as emissoras de televisão em sua busca alucinada pela audiência. Tal enxurrada de imagens provoca a sensação de cansaço visual, de saturação icônica. Os nossos olhos estão como que fatigados de tanto ver a mesma coisa, o mesmo acidente, a mesma morte trágica. Aí, a repetição mítica parece ultrapassar os limites de sua linguagem rítmica e simbólica para se tornar uma repetição, sobretudo, obsessiva.

A televisão é repetitiva, como o é a própria a violência. Mas por que tanta repetição? Para melhor compreender o princípio de repetição obsessiva, necessário se faz decifrar a dinâmica cultural que tem caracterizado a era pós-moderna: pulsação ofegante, velocidade, rapidez, fugacidade, prazer imediato, verborragia, excesso, inflação icônica. E o que vemos na TV: imagens em excesso, fala em excesso, repetições, repetições. A TV não para de se mostrar, através de imagens e discursos, numa profusão verborrágica interminável, infinita.

Essas repetições alucinadas da TV aproximam-se do discurso psicótico, (MARCONDES FILHO, 1988, p.84) na medida em que se produz infinitamente uma sobreposição de falas sobre falas, imagens sobre imagens, a tal ponto que o resultado final é um discurso vazio, incoerente e (quase) sem sentido. Baudrillard fala em "implosão do sentido nos media". Segundo ele, "estamos num universo em que existe cada vez mais informação e cada vez menos sentido" (BAUDRILLARD, 1991, p.103).

E essa perda de sentido está relacionada à ação dissolvente e dissuasiva da informação dos mass media. Neste sentido, afirma Baudrillard, a informação devora os seus próprios conteúdos, a própria comunicação social. E isto acontece por dois motivos: "a) em vez de fazer comunicar, esgota-se na encenação da comunicação; b) Em vez de produzir sentido, esgota-se na encenação do sentido" (BAUDRILLARD, 1991, p.105).

A propósito do processo de encenações e simulações nos meios de comunicação de massa, escreve Baudrillard:

Por detrás dessa encenação
exacerbada da comunicação,
os mass media, a informação
em 'forcing' prosseguem uma
desestruturação do real.(...) As-
sim, os mass media são produ-
tores não da socialização mas
do seu contrário, da implosão
do social nas massas. (BAU-
DRILLARD, 1991, p.106).

Segundo G. Durand (1988), essa explosão de imagens desencadeia um verdadeiro efeito perverso, isto é, as descobertas científicas ligadas ao desenvolvimento das imagens não implicaram na valorização do mundo imaginado, no desenvolvimento da criatividade simbólica. Entre outros efeitos perversos, o autor cita o "anestesiamento" 
gradual da criatividade individual da imaginação.

Para Durand (1988), trata-se, portanto, de um "olho morto", que contempla de igual forma acontecimentos trágicos ou cômicos de quaisquer partes do mundo, desde a África do Sul, Estados Unidos, Brasil, Bósnia, China ou o agreste do Piauí. Um olho cuja retina fatigada parece "anestesiada em sua criatividade". Ancorada na tecnoburocracia, na morosidade e na ineficiência dos serviços públicos, nas discrepâncias materiais da estrutura sócio-econômica, a violência tecnorracionalista é essencialmente diluidor das expectativas, dos desejos, das potencialidades do sujeito-receptor. As conseqüências práticas da violência tecnorracionalista junto ao indivíduo podem ser:

1) Dissuasão do sujeito, que aos poucos vai abandonando certos referenciais de crenças, ideologias, convicções pessoais e sociopolíticas; 2) Dissolução de suas potencialidades psicossocias e de seus relacionamentos afetivos; 3 ) Diluição de seus desejos, expectativas, sensibilidade, criatividade, da imaginação.

A espetacularização do real (diferente de espetáculo), promovida diariamente pela TV, contribui para a propulsão da violência tecnorracionalista, na medida em que a tudo transforma em simulacros (imagem mais "real" e mais "perfeita" que a própria realidade). Assim, como diz Baudrillard, promovem-se não simplesmente as simulações de realidades, mas, fundamentalmente, a desestruturação do real.

A banalização se constrói, não mediante a repetição mítica, mas através da repetição obsessiva e psicótica de certas imagens violentas. Ela se constrói através da saturação, do congestionamento de imagens. Então, se no passado (aristotelismo, cartesianismo, positivismo, racionalismo) havia um iconoclasmo por falta/repressão à imaginação simbólica, agora há um iconoclasmo por excesso de imagens.

O que predomina na cultura pós-moderna é, pois, uma inflação imaginária (inflação icônica), isto é, uma desvalorização da imaginação em função do excesso de circulação de imagens. Tal saturação provoca o que G. Durand (1988) chamou de "efeito perverso": a atual civilização cultiva a imagem, mas não a imaginação.

O resultado é preocupante: o olhar do receptor torna-se fatigado. Há, portanto, uma espécie de saturação icônica, um clima de indiferença imagético-sensitiva, uma sensação de impotência coletiva e individual, que pode se tornar crônica. As imagens da televisão brasileira de hoje situam-se, de maneira geral, no contexto desta estreiteza simbólica. Bachelard (1984) diz que as imagens da atualidade nos impedem de imaginar. ${ }^{4}$ A profusão incessante de ícones, a fabricação e a repetição excessiva de imagens, a banalização da violência, a simulação obsessiva da realidade, enfim, a saturação do olhar acaba por provocar uma volatilidade da imaginação criativa. O olhar torna-se, portanto, fatigado e socialmente indiferente. Com efeito, sufocam-se os espaços de ação e representação da cidadania plena, bem como a efetiva dos direitos humanos.
4 Segundo Teixeira Coelho, o iconoclasmo por excesso da televisão tem construído um certo "imaginário da morte". Assim, ao invés de se dizer "paraíso via Embratel", melhor seria classificar a TV como um "inferno via Embratel”. COELHO, T. "O imaginário da morte". In: NOVAES, A. (org.). A rede imaginária, op. cit., pp. 109-22. 


\section{Referências Bibliográficas}

ARENDT, H. Da violência. Brasília: Editora da UnB, 1985.

BACHELARD, G. A poética do espaço. São Paulo: Abril Cultural, 1984.

BAUDRILLARD, Jean. Simulacros e simulação. Lisboa: Relógio d'Água, 1991

COELHO, T. O imaginário da morte. In: NOVAES, A. (org.). A rede imaginária: televisão e democracia, São Paulo: Companhia das Letras, 2001.

COSTA, Jurandir F. Violência e psicanálise. Rio de Janeiro, Graal, 1986.

DURAND, G. A imaginação simbólica. São Paulo, Cultrix: Edusp, 1988.

MAFFESOLI, M. A violência totalitária: Ensaio de antropologia política. Rio de Janeiro: Zahar, 1981.

MAFFESOLI, M. Dinâmica da violência. São Paulo: Vértice, 1987.

MARCONDES FILHO, C. Televisão: a vida pelo vídeo. São Paulo: Moderna, 1988.

MICHAUD, Y. A violência. (Trad. L. Garcia). São Paulo: Ática, 1989.

MORAIS, R. O que é violência urbana. São Paulo: Brasiliense, 1981.

TILLY, C. From mobilization to revolution. Londres: Addison-Wesley, Reading Mass, 1978. 